\title{
Increased Severity of Foliar Diseases of Sweet Corn Infected with Maize Dwarf Mosaic and Sugarcane Mosaic Viruses
}

\author{
M. D. Meyer, and J. K. Pataky, University of Illinois, Department of Crop Sciences, Urbana, IL 61801
}

\begin{abstract}
Meyer, M. D., and Pataky, J. K. 2010. Increased severity of foliar diseases of sweet corn infected with maize dwarf mosaic and sugarcane mosaic viruses. Plant Dis. 94:1093-1099.

Maize dwarf mosaic (MDM), caused by Maize dwarf mosaic virus (MDMV) and Sugarcane mosaic virus (SCMV), is an economically important viral disease of sweet corn (Zea mays). MDM is known to increase the severity of fungal root rots and southern corn leaf blight (SCLB). The effect of infection with MDMV-A and SCMV on eight foliar diseases was evaluated on 32 sweet corn hybrids (27 MDM-susceptible hybrids and five MDM-resistant hybrids) in 2007, 2008, and 2009. Virus infection substantially increased the severity of five diseases, including: SCLB, northern corn leaf spot (NCLS), gray leaf spot (GLS), Diplodia leaf streak (DLS), and eyespot. Among MDM-susceptible hybrids, mean severity of SCLB, NCLS, GLS, DLS, and eyespot on virus-infected plants was typically double that of plants that were asymptomatic of viral infection. Three diseases were not substantially increased by MDM, including: common rust, northern corn leaf blight (NCLB), and Stewart's wilt. Virus infection appeared to affect the severity of diseases caused by necrotrophic foliar fungi that colonize mesophyll tissue. MDM did not appear to substantially affect the severity of diseases caused by pathogens that form haustoria or invade the vascular system. The extent to which SCLB severity is increased by MDM in terms of changes in level of host resistance also was determined. For MDM-susceptible hybrids, reactions to SCLB ranged from resistant to moderately susceptible in MDM-free treatments, but each of these hybrids was classified as moderately susceptible to susceptible when infected with MDMV-A and/or SCMV. The results of this experiment demonstrate the importance of breeding for MDM resistance, not only to control this important viral disease of sweet corn, but also to lower the potential for detrimental effects from several other foliar diseases that often are of minor importance on sweet corn in the absence of MDM.
\end{abstract}

Interactions between viral and fungal pathogens occur in many crops. In rice, infection by Hoja blanca virus increases susceptibility to brown spot caused by Cochliobolus miyabeanus (anamorph: Bipolaris oryzae) (16). Beet yellows virus infection increases the severity of Cercospora leaf spot in sugar beet (8). Increased susceptibility to Curvularia leaf spot in gladiolus is associated with viral infection (4,5). When infected with Bean yellow mosaic virus and Bean leaf roll virus, faba bean is more susceptible to infection by Botrytis fabae and B. cinerea (27). Virus infection also increases susceptibility to root rot in many crops, including cucumber $(2,26)$, pea $(6,11)$, and red clover (39).

Virus infection does not always increase susceptibility of plants to fungal diseases. Corn (Zea mays L.) infected with Maize

Corresponding author: J. K. Pataky

E-mail: j-pataky@illinois.edu

* The $e$-Xtra logo stands for "electronic extra" and indicates that five supplemental tables not included in the print edition are available online.

Accepted for publication 10 May 2010.

doi:10.1094/PDIS-94-9-1093

(C) 2010 The American Phytopathological Society streak virus was not more susceptible to downy mildew fungi compared to virusfree plants (9). Severity of foliar blight caused by Septoria apiicola was reduced on celery infected with Celery mosaic virus and Parsnip yellow fleck virus (1).

Maize dwarf mosaic (MDM), caused by Maize dwarf mosaic virus (MDMV) and/or by Sugarcane mosaic virus (SCMV), is the most prevalent viral disease of corn in the continental United States. Soon after MDM was described on corn (14), increased occurrence of fungal root rots was associated with infection by MDMV $(12,24,38,40)$. Root rots caused by $P y$ thium graminicola and Diplodia zeae, and seedling blights caused by Fusarium moniliforme, $F$. roseum, Penicillium funiculosum, $P$. oxalicum, and $P$. purpurogenum, were more severe in MDMVinfected plants than in virus-free plants (24). Incidence of $F$. moniliforme infection in sweet corn seedlings was $55 \%$ greater in MDMV-infected plants than in plants asymptomatic of MDMV infection (12). MDMV-infected corn seedlings also were more susceptible to root infections caused by Gibberella zeae and Helminthosporium pedicellatum (38).

Southern corn leaf blight (SCLB), caused by Bipolaris maydis (Nisikado \& Miyake) Shoemaker, is the only foliar disease of corn known to be increased by
MDMV infection (3,35). Severity of SCLB caused by $B$. maydis races $\mathrm{T}$ and $\mathrm{O}$ was greater on MDMV-infected corn plants than on healthy plants $(3,35)$. Watersoaking prior to lesion development, lesion size, lesion number, and sporulation were greater on leaf sections from MDMVinfected plants than from noninfected plants (3).

Altered permeability of plant tissues and increased exudates may cause increased susceptibility to B. maydis in MDMVinfected corn plants (35). Several physiological and cytological changes occur in MDMV-infected cells of corn and sorghum, including a reduction in size and number of chloroplasts, an increase in nuclear material, and degradation of the mesophyll cells $(3,25)$. Reduced rates of photosynthesis and higher rates of respiration also result from MDMV infection (37).

Although increased susceptibility to fungal root rots and SCLB in MDMVinfected corn plants is well documented, the effects of MDM on other foliar diseases of sweet corn are unknown. Several foliar diseases are economically important on sweet corn, including: common rust caused by Puccinia sorghi Schwein, northern corn leaf blight (NCLB) caused by Exserohilum turcicum (Pass.) K.J. Leonard \& E.G. Suggs, Stewart's wilt caused by Pantoea stewartii subsp. stewartii (Smith) Mergaert et al., and southern corn leaf blight (SCLB). About 300 to 400 commercial and precommercial sweet corn hybrids and inbreds are screened annually in the University of Illinois disease nursery for their reaction to these and other prevalent diseases (29). In the 2006 disease nursery, symptoms of SCLB were substantially more severe on sweet corn plants with symptoms of MDM than on plants asymptomatic of viral diseases $(20,32)$.

The objectives of this study were to quantify the extent to which SCLB severity is increased by MDM in terms of changes in level of host resistance and to determine if MDM increases the severity of other foliar diseases of sweet corn, including common rust, NCLB, Stewart's wilt, northern corn leaf spot (NCLS) caused by Bipolaris zeicola (G.L. Stout) Shoemaker, Diplodia leaf streak (DLS) caused by Stenocarpella macrospora (Earle) Sutton, eyespot caused by Kabatiella zeae Narita \& Hiratsuka, and gray leaf spot (GLS) caused by Cercospora zeae-maydis Tehon \& E.Y. Daniels. 


\section{MATERIALS AND METHODS}

Sweet corn hybrid disease nursery observations. While rating sweet corn hybrids for SCLB as part of the 2006 University of Illinois sweet corn hybrid disease nursery $(20,32)$, symptoms of SCLB appeared to be more severe on individual plants infected with MDMV and SCMV than on adjacent plants of the same hybrid that were asymptomatic of viral infection (i.e., MDM-free). To confirm this observation, virus-infected and MDM-free plants in plots of 75 different hybrids were rated for SCLB symptoms using a 1 to 9 scale described below. Two leaves were sampled from adjacent virus-infected and MDMfree plants of each hybrid. Lesion length was measured from five lesions per leaf. Lesions were counted in two $9 \mathrm{~cm}^{2}$ areas of each leaf. Ratings, lesion length, and number of lesions were compared by paired $t$ tests $(P \leq 0.05)$ of adjacent virusinfected and MDM-free plants.

MDM and foliar disease interactions. Field trials were done in 2007, 2008, and 2009 at the University of Illinois Vegetable Crops Research Farm, Champaign, IL. Each trial included 32 commercial sweet corn hybrids with known reactions to MDM. Twenty-seven hybrids were susceptible to MDM. Five MDM-resistant hybrids were included as controls. MDM resistance is inherited as a single dominant gene on maize chromosome $6 \mathrm{~S}$ with an unspecified number of modifier genes affecting phenotypic responses. When inoculated with MDMV and/or SCMV, plants of MDM-resistant hybrids are asymptomatic, although all MDM-resistant sweet corn hybrids have a low incidence of systemically infected, symptomatic plants following inoculation at very early vegetative growth stages, i.e., the two- to threeleaf stage, when leaf collars are visible on the second or third leaves (J. K. Pataky, personal observation).

Six foliar diseases (common rust, GLS, NCLB, NCLS, SCLB, and Stewart's wilt) were evaluated in separate experiments. Each experimental design was a split-plot arrangement of a randomized complete block with four replicates. Hybrids were grown in main plots, and virus treatments were applied to subplots in 2007. In 2008 and 2009, virus treatments were applied to main plots, and hybrids were grown in subplots. An experimental unit was one 3.5-m-long row with approximately 16 plants. Rows were spaced $76 \mathrm{~cm}$ apart. Trials were planted on 14 May 2007, 29 May 2008, and 29 May 2009.

DLS and eyespot trials. Trials assessing the effect of MDM on DLS and eyespot were done in 2009. Each disease was evaluated in two separate trials planted on 29 May and 9 June. Four MDMsusceptible hybrids were grown. The experimental design was a split-plot arrangement of a randomized complete block design with four replicates. Viral treatments were applied to main plots and hybrids were grown in subplots. An experimental unit was one 3.5 -m-long row with approximately 16 plants. Rows were spaced $76 \mathrm{~cm}$ apart.

Viral treatments. All trials included two viral treatments: a noninoculated control and plants inoculated with a combination of strain A of MDMV (MDMV-A) and SCMV. In three additional SCLB trials, plants were inoculated with either MDMVA (2008 and 2009) or SCMV (2008). Occasional occurrences of plants symptomatic of viral infection in noninoculated plots (possibly due to mechanical transmission, aphid vectors, etc.) were removed by hoeing as soon as symptoms were observed and prior to rating symptoms of fungal and bacterial diseases in these plots.

MDMV-A-infected Johnsongrass (Sorghum halepense) and SCMV-infected sweet corn plants were maintained in a greenhouse to provide a source of inoculum. To increase inoculum, MDMsusceptible sweet corn hybrids were inoculated in isolated field plots in early May. Fields of plants inoculated with MDMV-A or SCMV for the purpose of increasing inoculum were separated by at least $400 \mathrm{~m}$. Inoculum from these fields was prepared prior to the arrival of aphid vectors of the viruses.

Leaves of MDMV-A- and SCMVinfected plants were collected from inoculum increase fields. Infectious sap was extracted by blending equal quantities of MDMV-A- and SCMV-infected tissue in $0.1 \mathrm{M}$ potassium phosphate buffer at $\mathrm{pH} 7$ (approximately $1 \mathrm{~g}$ of leaf tissue per $10 \mathrm{ml}$ of buffer) for approximately $30 \mathrm{~s}$. The homogenate was filtered through a 3.8-liter paint strainer (Trimaco LLC, Durham, NC). Inoculum was prepared by mixing approximately 3.8 liters of infectious sap extracted from MDMV-A- and SCMVinfected tissue, 7.6 liters of $0.1 \mathrm{M}$ potassium phosphate buffer, and $13 \mathrm{~g}$ of $320-$ grit Carborundum powder. Plants at the three- to four-leaf stage (i.e., number of leaves with visible collars) were mechanically inoculated twice using a motorized mist blower (Model 444; Solo, Newport News, VA) on 8 and 11 June 2007, 17 and 18 June 2008, 15 and 19 June 2009, and 30 June and 1 July 2009.

Inoculation procedures and maintenance of pathogen cultures. Plants were inoculated with fungal or bacterial pathogens 7 to 10 days after viral inoculations. Dates of inoculation varied among years and diseases. Suspensions of about $10^{3}$ conidia per ml plus mycelial fragments of B. maydis, B. zeicola, E. turcicum, C. zeaemaydis, S. macrospora, or K. zeae were sprayed directly into leaf whorls between the four- to seven-leaf stages to initiate primary infection. Inoculum was prepared by blending 10- to 14-day-old cultures in water. Cultures were grown at room tem- perature (24 to $26^{\circ} \mathrm{C}$ ) under diurnal fluorescent light. B. maydis, B. zeicola, and $E$. turcicum were cultured on lactose-casein hydrolysate agar (LCA) and on sterile sorghum seeds. C. zeae-maydis (isolates obtained from D. G. White, University of Illinois, Urbana) was cultured on V8 agar. $S$. macrospora (isolates obtained from C. A. Bradley, University of Illinois, Urbana) was cultured on potato dextrose agar (PDA) amended with autoclaved corn leaves (18) and a synthetic medium described by Morant et al. (23). K. zeae (isolates obtained from J. G. Kinsey, Monsanto Co., Waterloo, IL) was cultured on PDA.

Suspensions of $P$. sorghi urediniospores also were sprayed directly into leaf whorls to initiate primary infection. Urediniospores of $P$. sorghi were collected from infected plants in plots used to increase inoculum similar to those used to increase MDMV-A and SCMV. Urediniospores were suspended in water with a few drops of Tween 20. Urediniospores collected the previous summer were maintained at $-80^{\circ} \mathrm{C}$ until inoculum was increased in early-planted fields.

Pantoea stewartii was isolated from infected plants collected throughout Illinois as described previously (36). Plants between the four- to six-leaf stage were inoculated with $P$. stewartii using the pinprick inoculation method (7).

Disease assessments. Incidence of plants symptomatic of virus infection was measured in each experimental unit 7 to 10 days after inoculation. Severity of seven foliar diseases (common rust, DLS, eyespot, GLS, NCLB, NCLS, SCLB) was rated visually on a row basis 1 to 3 weeks after anthesis. GLS was rated on a 1 to 9 scale of severity (Supplemental Table 1), where $1=$ chlorotic flecks with little secondary spread and $9=$ dense bands of necrotic rectangular lesions with abundant secondary spread (30). NCLS was rated on a 1 to 9 scale of severity (Supplemental Table 2), where $1=$ chlorotic flecks and 9 $=$ dense necrotic bands of the "strand of pearls" symptom with abundant secondary spread (19). SCLB was rated on a 1 to 9 scale (Supplemental Table 3), where $1=$ chlorotic flecks and $9=$ large necrotic spots with more than $75 \%$ of tissue blighted (19). Eyespot was rated on a 1 to 5 scale (Supplemental Table 4), where $1=$ few necrotic spots less than $1 \mathrm{~mm}$ with chlorotic halos and $5=$ necrotic spots greater than 2 to $3 \mathrm{~mm}$ with abundant secondary spread (19). The percentage of total symptomatic leaf area was rated from 0 to $100 \%$ for common rust, DLS, and NCLB. Severity of Stewart's wilt was rated about 14 to 21 days after inoculation on a 1 to 9 scale (Supplemental Table 5; 36). Each experimental unit was rated separately by two people. Ratings were averaged for each experimental unit. Disease ratings generally reflected secondary infection 
rather than primary infection resulting from inoculation.

Statistical analysis. Because the arrangement of treatments differed among years, analyses were done separately for each year. Severity ratings for each foliar disease were analyzed by analysis of variance (ANOVA) using the Proc Mixed procedure of SAS version 9.2 (SAS Institute, Cary, NC). Data were analyzed twice, with and without MDM-resistant hybrid controls in the analyses. Blocks and hybrids treatments were considered fixed variables. Effects were declared significant at $P \leq$ 0.05 unless otherwise stated. Sums of squares were examined to identify the portion of total variation accounted for by treatment main effects and the interaction term. Residuals were tested for normality using the Proc Univariate procedure of SAS. Residuals were plotted against predicted values using the Proc Gplot procedure of SAS to assess homogeneity of error variance.

Effect of MDM on hybrid reactions to SCLB. Hybrid reactions to SCLB were used to determine the effect of virus infection on host resistance to SCLB. Because severity of SCLB was affected similarly by MDMV-A, SCMV, or the combination of MDMV-A and SCMV, ratings were averaged for all five SCLB trials. For each combination of hybrid and viral treatment, z-scores of SCLB severity were calculated using the mean and standard deviation of the noninoculated treatment. Criteria used to classify hybrid reactions to SCLB were based on the mean of z-scores used as boundaries for SCLB reaction categories were considered random variables. Viral

in nine previous University of Illinois sweet corn disease nurseries (Table 1). Although this procedure produces statistically "overlapping" groups without clearcut differences among hybrids in adjacent categories (e.g., the hybrids with the least severe symptoms in the MR class may not differ significantly from the hybrids with the most severe symptoms in the R class), a consistent response of a hybrid over several trials produces a reasonable estimate of the disease reaction of that hybrid relative to the response of other hybrids.

\section{RESULTS}

Sweet corn hybrid disease nursery observations. Southern corn leaf blight ratings, lesion length, and number of lesions per $9 \mathrm{~cm}^{2}$ of leaf were significantly greater for virus-infected plants than for MDMfree plants (Table 2). Mean SCLB ratings for virus-infected plants and MDM-free plants were 5.1 and 3.1, respectively; however, MDM affected SCLB to a greater extent on hybrids that had higher levels of SCLB resistance. The difference in mean SCLB ratings on virus-infected and MDMfree plants was $2.5,2.3,1.7$, and 1.4, for hybrids with SCLB ratings from 1 to 2 , above 2 to 3 , above 3 to 4 , and above 4 , respectively (Table 2 ). Lesions were about 1.2 to $1.5 \mathrm{~cm}$ longer on virus-infected plants than on MDM-free plants. There were about two more lesions per $9 \mathrm{~cm}^{2}$ of leaf area of virus-infected plants.

MDM and foliar disease interactions. The effect of MDM on disease severity differed among the eight foliar diseases evaluated. Severity of five diseases (SCLB, NCLS, GLS, DLS, and eyespot) was in-

Table 1. Standard z-scores used to classify sweet corn hybrids into nine categories of disease reaction to southern corn leaf blight (SCLB)

\begin{tabular}{ll}
\hline Disease reaction & z-score $^{\mathbf{a}}$ \\
\hline 1 Resistant & $\leq-1.2$ \\
2 Resistant to moderately resistant & $>-1.2$ and $\leq-0.7$ \\
3 Moderately resistant & $>-0.7$ and $\leq-0.3$ \\
4 Moderately resistant to moderate & $>-0.3$ and $\leq 0.2$ \\
5 Moderate & $>0.2$ and $\leq 0.6$ \\
6 Moderate to moderately susceptible & $>0.6$ and $\leq 1.3$ \\
7 Moderately susceptible & $>1.3$ and $\leq 2.0$ \\
8 Moderately susceptible to susceptible & $>2.0$ and $\leq 2.9$ \\
9 Susceptible & $>2.9$ \\
\hline
\end{tabular}

${ }^{a} \mathrm{Z}$-scores used as boundaries between resistance categories are the means of $\mathrm{Z}$-scores used to classify reactions in nine previous University of Illinois sweet corn disease nurseries. creased substantially by virus infection. Three diseases (common rust, NCLB, and Stewart's wilt) were not affected substantially. When analyses of disease ratings for SCLB, NCLS, and GLS included MDMresistant and MDM-susceptible hybrids, viral treatments accounted for 44 to $71 \%$ of the total variation, and the hybrid by virus interaction term accounted for 6 to $18 \%$ of the total variation in the ANOVAs (Table 3). When disease severity ratings for SCLB, NCLS, GLS, DLS, and eyespot were analyzed excluding MDM-resistant hybrids, viral treatments accounted for 56 to $87 \%$ of the total variation, and the hybrid by virus interaction term accounted for only 2 to $8 \%$ of the total variation in the ANOVAs (Table 3). The significance of the hybrid by viral treatment interaction term resulted primarily from responses of MDM-resistant hybrids and from differences in susceptibility to foliar diseases among the other 27 hybrids evaluated. For example, ratings of SCLB severity on hybrids susceptible to that disease were affected less by MDM than by SCLB severity on hybrids with resistance to SCLB because that disease was already severe on SCLB-susceptible hybrids regardless of whether they were virus infected or asymptomatic of MDM (Fig. 1).

Among MDM-susceptible hybrids, mean ratings of SCLB, NCLS, GLS, DLS, and eyespot severity on virus-infected plants were typically double those of MDM-free plants (Figs. 2A and $3 \mathrm{~A}$ and $\mathrm{B}$ ). SCLB ratings and differences among virus-infected and MDM-free treatments were similar among trials where MDMV-A and SCMV were inoculated separately or in combination, indicating that infection by either virus or the mixture of viruses had a similar effect on host susceptibility to SCLB. Except for the SCLB-B trial in 2008, disease severity ratings for MDMresistant hybrids did not differ significantly among virus-infected and MDM-free treatments (Fig. 2B).

MDM did not substantially increase severity of common rust, NCLB, or Stewart's wilt (Table 3; Fig. 4A and B). Although the main effect of viral treatments and the hybrid by viral treatment interaction were significant in some of the ANOVAs of common rust, NCLB, and Stewart's wilt ratings, viral treatments only

Table 2. Southern corn leaf blight (SCLB) ratings, and lesion length and number on adjacent plants of 75 sweet corn hybrids infected with maize dwarf mosaic (MDM) and sugarcane mosaic viruses or asymptomatic of viral infection (MDM-free)

\begin{tabular}{|c|c|c|c|c|c|c|c|}
\hline \multirow{2}{*}{$\begin{array}{l}\text { MDM-free } \\
\text { SCLB rating }\end{array}$} & \multirow[b]{2}{*}{$n^{\mathbf{b}}$} & \multicolumn{2}{|c|}{ SCLB rating ${ }^{\mathrm{a}}$} & \multicolumn{2}{|c|}{ Lesion length $(\mathrm{cm})$} & \multicolumn{2}{|c|}{ No. of lesions $/ 9 \mathrm{~cm}^{2}$} \\
\hline & & MDM-free & Virus-infected & MDM-free & Virus-infected & MDM-free & Virus-infected \\
\hline 1 to 2 & 16 & $1.9^{* \mathrm{c}}$ & 4.4 & $0.8^{*}$ & 2.0 & $4.3^{*}$ & 5.8 \\
\hline$>2$ to 3 & 21 & $2.7 *$ & 5.0 & $0.9 *$ & 2.1 & $4.5^{*}$ & 6.9 \\
\hline$>3$ to 4 & 30 & $3.6^{*}$ & 5.3 & $0.9 *$ & 2.3 & $5.2 *$ & 7.3 \\
\hline$>4$ & 8 & $4.8^{*}$ & 6.1 & $1.1 *$ & 2.6 & 5.8 & 6.1 \\
\hline Mean & $\ldots$ & $3.1 *$ & 5.1 & $0.9 *$ & 2.2 & $4.8 *$ & 6.7 \\
\hline
\end{tabular}

a SCLB rating: 1 to 9 scale, where $1=$ chlorotic flecks and $9=$ large, necrotic spots and with more than $75 \%$ of tissue symptomatic (19).

${ }^{\mathrm{b}} n=$ number of symptomatic pairs of adjacent healthy and MDM-infected plants sampled. Each sample was a different sweet corn hybrid.

${ }^{\mathrm{c}}$ Means for MDM-free plants followed by an asterisk are significantly different from means for virus-infected plants based on paired $t$ tests $(P \leq 0.05)$. 
accounted for 0 to $19 \%$ of the total variation for these foliar diseases compared to 44 to $87 \%$ for the other five foliar diseases (Table 3). Mean ratings of common rust, NCLB, and Stewart's wilt severity did not differ substantially on virus-infected plants and MDM-free plants except for NCLB severity in 2008 (Fig. 4A and B). On MDM-susceptible hybrids, mean severity ratings for common rust in 2007, NCLB in 2007, and Stewart's wilt in 2009 were significantly, but not substantially, greater on virus-infected plants than on MDM-free plants (Fig. 4A). In 2009, mean NCLB severity was 39 and $52 \%$ on MDM-free and virus-infected plants, respectively. Although severity of Stewart's wilt infection was not appreciably different among viral treatments, chlorotic, water-soaked tissues symptomatic of Stewart's wilt senesced more rapidly on virus-infected plants than on MDM-free plants. More rapid tissue senescence may have caused the difference in Stewart's wilt ratings in 2009. On MDM-resistant plants, severity of common rust, NCLB, and Stewart's wilt did not differ between the two viral treatments (Fig. 4B).

Effects of MDM on SCLB resistance. Among the five SCLB trials, SCLB ratings for MDM-free hybrids ranged from 1.8 to 4.7 , with a mean of 3.3 and standard deviation of 0.8 (Table 4). For virus-infected hybrids, SCLB ratings ranged from 4.4 to 7.3 , with a mean of 5.6 and standard deviation of 0.9, excluding MDM-resistant hybrids. Z-scores of SCLB ratings calculated from grand means and standard deviations from the MDM-free treatments ranged from -1.9 to 1.5 among MDM-free hybrids and from 1.4 to 7.0 among virus-infected hybrids. For MDM-susceptible hybrids, reactions to SCLB ranged from resistant to moderately susceptible in MDM-free treatments, but each of these hybrids was classified as moderately susceptible to susceptible to SCLB when infected with MDMV-A and/or SCMV (Table 4). Reactions to SCLB did not differ appreciably

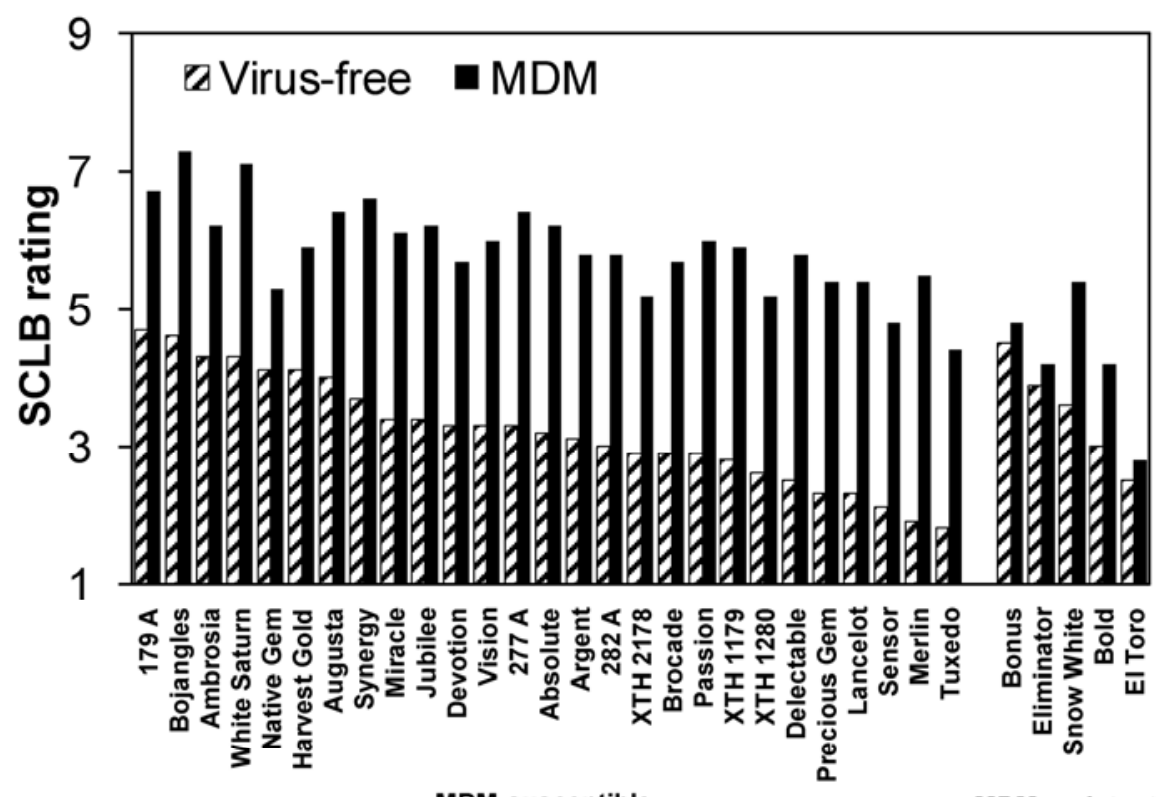

\section{Hybrid and MDM reaction}

Fig. 1. Mean ratings of southern corn leaf blight (SCLB) on sweet corn hybrids infected by Maize dwarf mosaic virus and/or Sugarcane mosaic virus or on hybrids free of symptoms of viral infection (virus-free) in field trials at Urbana, IL assessing the effect of maize dwarf mosaic (MDM) on SCLB severity.

Table 3. Sum of squares for treatment sources of variation expressed as percentages of the total variation from analysis of variance (ANOVA) of disease severity based on factorial experiments with 32 sweet corn hybrids and two maize dwarf mosaic (MDM) treatments

\begin{tabular}{|c|c|c|c|c|c|c|c|c|}
\hline \multirow[b]{3}{*}{ Foliar disease } & \multirow[b]{3}{*}{ MDM $^{d}$} & \multirow[b]{3}{*}{ Year } & \multicolumn{6}{|c|}{ Percentage (\%) of total sums of squares ${ }^{a}$} \\
\hline & & & \multicolumn{3}{|c|}{ ANOVA with MDM-R hybrids ${ }^{b}$} & \multicolumn{3}{|c|}{ ANOVA without MDM-R hybrids ${ }^{\mathrm{c}}$} \\
\hline & & & Hybrid ${ }^{e}$ & Virus $^{\mathrm{e}}$ & Hybrid $\times$ virus $^{\mathrm{e}}$ & Hybride & Virus $^{\mathrm{e}}$ & Hybrid $\times$ virus $^{\mathrm{e}}$ \\
\hline \multirow{2}{*}{ Diplodia leaf streak } & $\mathrm{AB}$ & 2009 & $\ldots^{\mathrm{f}}$ & $\ldots$ & $\ldots$ & 3 & $87 * * * \mathrm{~g}$ & 2 \\
\hline & & 2009 & $\ldots$ & $\ldots$ & $\ldots$ & 7 & $82 * * *$ & $7 * * *$ \\
\hline \multirow{2}{*}{ Eyespot } & $\mathrm{AB}$ & 2009 & $\ldots$ & $\ldots$ & $\ldots$ & 15 & $80 * *$ & $2 * *$ \\
\hline & & 2009 & & & & 8 & $77 * *$ & $8 * *$ \\
\hline \multirow[t]{2}{*}{ Gray leaf spot } & $\mathrm{AB}$ & 2007 & 21 & $44 * * *$ & $11 * * *$ & $16^{*}$ & $56 * * *$ & $5^{* *}$ \\
\hline & & 2009 & 9 & $67 * * *$ & $7 * * *$ & 4 & $81 * * *$ & $4 * *$ \\
\hline \multirow[t]{2}{*}{ Northern corn leaf spot } & $\mathrm{AB}$ & 2007 & $24^{*}$ & $54 * * *$ & $10 * * *$ & $18 * * *$ & $66 * * *$ & $4 * * *$ \\
\hline & & 2009 & 21 & $57 * * *$ & $18^{* * *}$ & 11 & $77 * * *$ & $8 * * *$ \\
\hline \multirow[t]{2}{*}{ Southern corn leaf blight } & $\mathrm{AB}$ & 2007 & 24 & $52 * * *$ & $13 * * *$ & $17 * *$ & $67 * * *$ & $5 * * *$ \\
\hline & & 2008 & $20 * *$ & $68 * * *$ & $7 * * *$ & $17 * * *$ & $75 * * *$ & $3 * * *$ \\
\hline \multirow[t]{2}{*}{ Southern corn leaf blight } & A & 2008 & $22 * *$ & $62 * * *$ & $9 * * *$ & $18 * * *$ & $71 * * *$ & $4 * * *$ \\
\hline & & 2009 & 24 & $47 * * *$ & $14 * * *$ & $18^{*}$ & $62 * * *$ & $6 * * *$ \\
\hline Southern corn leaf blight & B & 2008 & $16^{* * *}$ & $71 * *$ & $6 * * *$ & $13 * *$ & $77 * * *$ & $4 * * *$ \\
\hline \multirow[t]{2}{*}{ Common rust } & $\mathrm{AB}$ & 2007 & $62 * * *$ & $8 * * *$ & $8 * * *$ & $48 * * *$ & $14 * * *$ & $12 * * *$ \\
\hline & & 2008 & $83 * * *$ & 0 & $4 * *$ & $52 * * *$ & 0 & $14 * * *$ \\
\hline \multirow[t]{2}{*}{ Northern corn leaf blight } & $\mathrm{AB}$ & 2007 & $64 * * *$ & $6 * * *$ & $5 * * *$ & $63 * * *$ & $8 * * *$ & $4 * *$ \\
\hline & & 2008 & $54 * * *$ & $16^{*}$ & $7 * * *$ & $54 * * *$ & $19 * *$ & $5 * * *$ \\
\hline \multirow{2}{*}{ Stewart's wilt } & $\mathrm{AB}$ & 2008 & $62 * * *$ & 3 & 6 & $52 * * *$ & 5 & 7 \\
\hline & & 2009 & $69 * * *$ & $7 *$ & $5^{*}$ & $61 * * *$ & $10 *$ & 4 \\
\hline
\end{tabular}

a Treatment sum of squares divided by total sums of squares multiplied by 100 .

${ }^{\mathrm{b}}$ Data analyzed with 27 MDM-susceptible and five MDM-resistant hybrid controls.

${ }^{c}$ Data analyzed without five MDM-resistant hybrid controls.

${ }^{\mathrm{d}}$ MDM inoculation treatment, where $\mathrm{AB}=$ inoculation with Maize dwarf mosaic virus strain A (MDMV-A) and Sugarcane mosaic virus (SCMV); $\mathrm{A}=$ inoculation with MDMV-A only; B = inoculation with SCMV only.

${ }^{\mathrm{e}}$ Sources of treatment variation from ANOVA where hybrid = 27 MDM-resistant and 5 MDM-susceptible hybrids; virus = inoculated with MDMV-A and/or SCMV; and hybrid $\times$ virus $=$ interaction of hybrid by virus main effects.

f $\ldots=$ MDM-resistant hybrids not included in experiment.

$\mathrm{g}$ Asterisks indicate corresponding mean squares statistically significant, where $*=P<0.05, * *=P<0.01$, and $* * *=P<0.001$. 
among viral treatments for three MDMresistant hybrids (El Toro, Eliminator, and Bonus) (Table 4). SCLB reactions were increased for two MDM-resistant hybrids (Bold and Snow White) that have lower levels of MDM resistance. Possibly, this was due to 30 to $50 \%$ incidence of virusinfected plants of Bold and Snow White from inoculation with MDMV-A and/or SCMV-B. Reactions of hybrids to SCLB based on 2 to 15 years of evaluation in University of Illinois disease nurseries were highly correlated with SCLB reactions and mean SCLB severity ratings from MDM-free treatments with correlation coefficients of 0.81 and 0.85 , respectively (Table 4).

\section{DISCUSSION}

Maize dwarf mosaic increased the severity of at least five foliar diseases of sweet corn, including SCLB, NCLS, GLS, DLS, and eyespot. Increased severity of MDMV- infected plants to SCLB was known previously $(3,35)$. Severity of common rust, NCLB, and Stewart's wilt were not affected substantially by MDM. Thus, MDM appears to affect the severity of diseases caused by necrotrophic foliar fungi that colonize mesophyll tissue. Increased susceptibility likely results from the degradation of mesophyll cells (25), cellular leakage, and altered permeability of virusinfected host tissues (35). Maize dwarf mosaic did not appear to substantially affect $P$. sorghi, which forms haustoria, or E. turcicum and $P$. stewartii, which invade the vascular system.

Pazur et al. (33) reported previously that MDM did not affect severity of common rust on sweet corn. Others have noted that virus infection did not increase the severity of rust diseases caused by Puccina recondita f. sp. tritici, P. hordei, or P. coronata f. sp. avenae in small grains $(17,34)$. Some viruses inhibit rust development $(10,41)$.

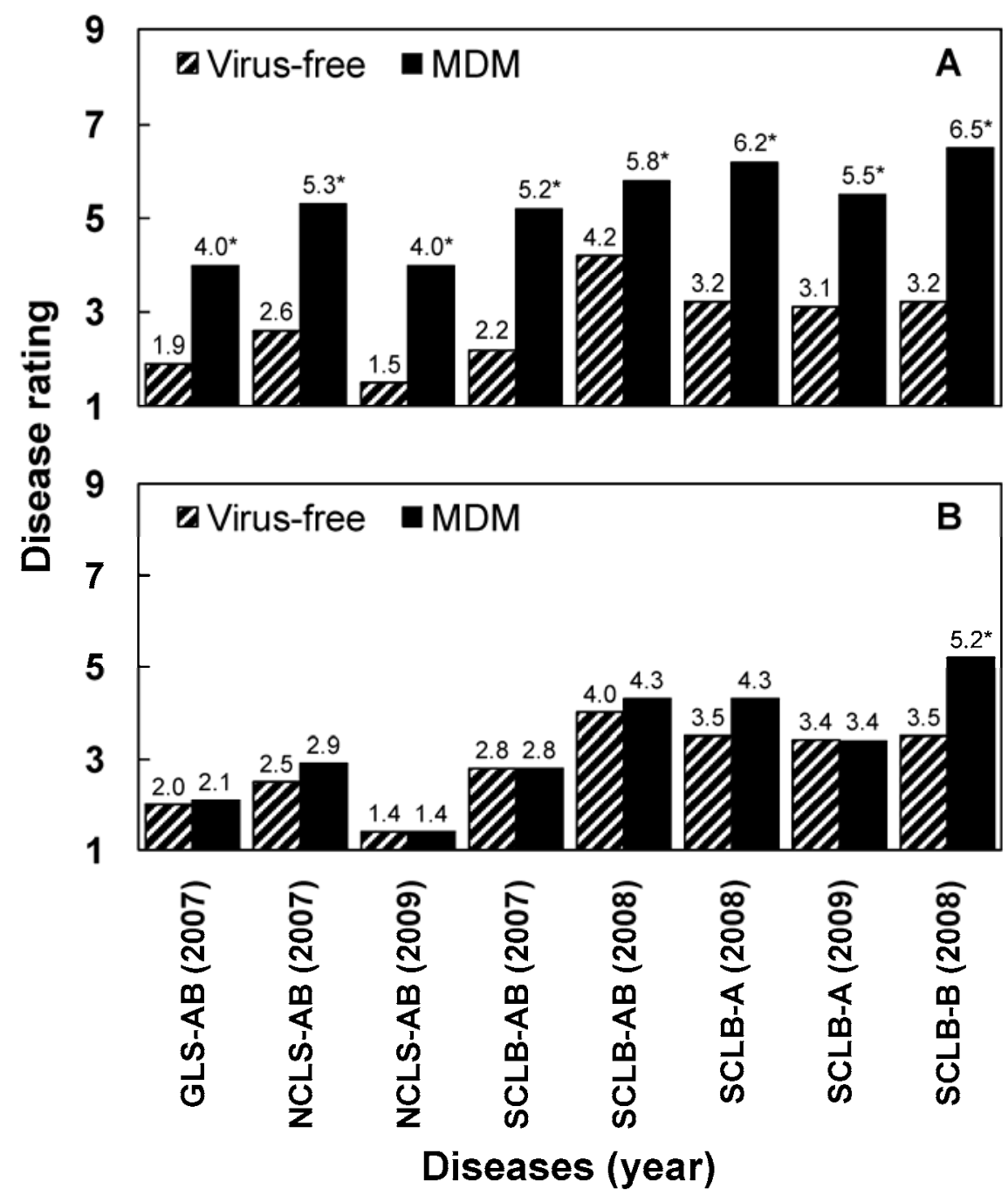

Fig. 2. Mean ratings of gray leaf spot (GLS), northern corn leaf spot (NCLS), and southern corn leaf blight (SCLB) on sweet corn hybrids infected by Maize dwarf mosaic virus (MDMV) and/or Sugarcane mosaic virus (SCMV) or on hybrids free of symptoms of viral infection (virus-free) in field trials at Urbana, IL: A, maize dwarf mosaic (MDM)-susceptible and B, MDM-resistant hybrids. Trials were inoculated with MDMV-A and SCMV (AB), MDMV-A only (A), or SCMV only (B). Asterisk indicates the virus-infected treatment (MDM) was significantly different from the virus-free treatment at $P$ $\leq 0.05$.

Severity of NCLB was significantly increased by MDM, but to a lesser extent than other fungal foliar diseases that primarily colonize mesophyll tissue. Perhaps NCLB severity is increased slightly because the size of lesions is affected by the ability of E. turcicum to grow in mesophyll tissue as well as in vascular bundles. Nevertheless, NCLB severity was not increased as substantially by virus infection as was the severity of the other necrotrophic foliar fungal diseases. Stewart's wilt ratings possibly were higher in virusinfected plants in 2009 because tissues with symptoms of Stewart's wilt senesced more rapidly on virus-infected plants than on MDM-free plants. Spread of Stewart's wilt symptoms throughout plants did not differ appreciably between virus-infected plants and MDM-free plants.

MDM substantially affected hybrid resistance reactions to SCLB. Disease reactions are used to assess the potential for diseases to become severe on a particular hybrid. Although the hybrids selected for this experiment were known to have a wide range of reactions to SCLB, all of the MDM-susceptible hybrids were classified as moderately susceptible to susceptible to SCLB when infected by MDMV and/or SCMV. Maize dwarf mosaic likely has a similar effect on hybrid reactions to several other foliar diseases based on the substan-
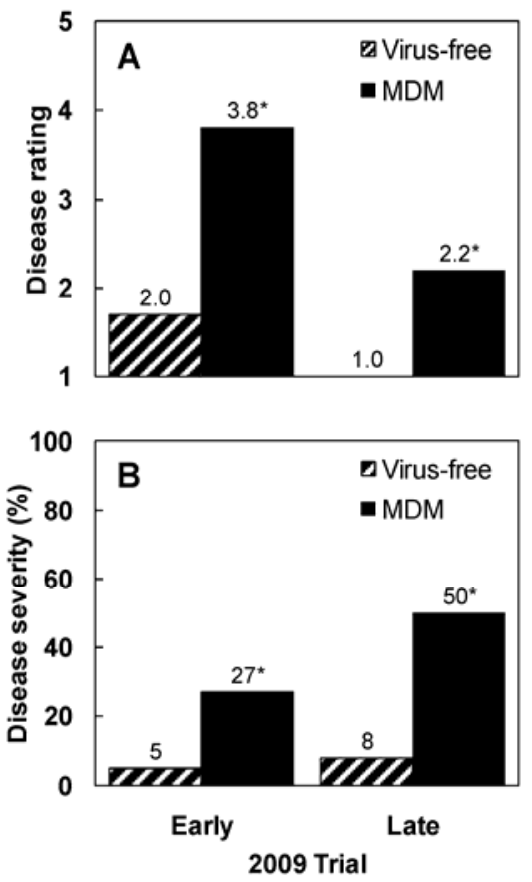

Fig. 3. Mean disease severity ratings for $\mathbf{A}$, eyespot and $\mathbf{B}$, Diplodia leaf streak on maize dwarf mosaic (MDM)-susceptible sweet corn hybrids infected by Maize dwarf mosaic virus and/or Sugarcane mosaic virus or on hybrids free of symptoms of viral infection (virus-free) in two field trials planted 29 May (early) or 9 June (late) 2009 at Urbana, IL. Asterisk indicates the virus-infected treatment (MDM) was significantly different from the virus-free treatment at $P \leq 0.05$. 


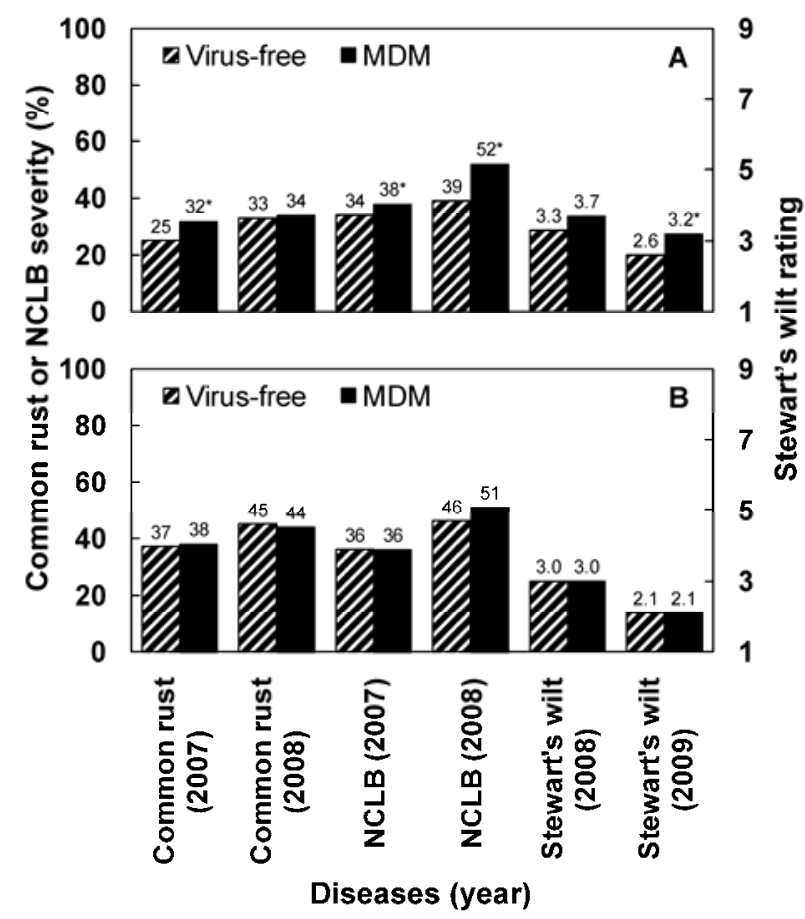

Fig. 4. Mean ratings of common rust, northern corn leaf blight (NCLB), and Stewart's wilt on sweet corn hybrids infected by Maize dwarf mosaic virus and/or Sugarcane mosaic virus or on hybrids free of symptoms of viral infection (virus-free) in field trials at Urbana, IL: A, maize dwarf mosaic (MDM)-susceptible and B, MDM-resistant hybrids. Asterisk indicates the virus-infected treatment (MDM) was significantly different from the virus-free treatment at $P \leq 0.05$. tial increases in severity ratings we observed in this study. In the presence of MDM, these foliar diseases, which usually are of minor importance on sweet corn, could be severe due to reduced levels of resistance.

Growing MDM-resistant hybrids is the most practical method of controlling MDM and preventing increased susceptibility to foliar diseases associated with virus infection. Although MDM resistance is generally successful in preventing MDM development, no MDM-resistant hybrid has $100 \%$ incidence of asymptomatic plants when inoculated at the two- to three-leaf stage (15). MDM is endemic on sweet corn in areas such as the lower Ohio River bottomlands and the Central Valley of California. It also occurs sporadically in many other areas where sweet corn is produced. In addition to the adverse effects of MDM on sweet corn yield $(13,15,21$, 22,31), MDMV- or SCMV-infected plants may experience increased susceptibility to several other foliar diseases. While these diseases typically are of minor importance on sweet corn, their increased severity on virus-infected plants may contribute to yield losses that typically are attributed to MDM. Thus, breeding for MDM resis-

Table 4. Hybrid reactions to southern corn leaf blight (SCLB) and maize dwarf mosaic (MDM), mean severity of SCLB on MDM-free and virus-infected plants in five trials, and resistance reactions of hybrids based on mean SCLB severity from those trials

\begin{tabular}{|c|c|c|c|c|c|c|}
\hline \multirow{2}{*}{$\begin{array}{l}\text { MDM reaction } \\
\text { and hybrid }\end{array}$} & \multicolumn{2}{|c|}{ Hybrid reaction $^{\mathrm{a}}$} & \multicolumn{2}{|c|}{ MDM-free } & \multicolumn{2}{|c|}{ Virus-infected } \\
\hline & $\mathbf{M D M}^{\mathbf{b}}$ & SCLB $^{b}$ & Mean SCLB severity & SCLB reaction ${ }^{b}$ & Mean SCLB severity & SCLB reaction ${ }^{b}$ \\
\hline \multicolumn{7}{|l|}{ Susceptible } \\
\hline Tuxedo & $9^{7}$ & $2^{9}$ & 1.8 & 1 & 4.4 & 7 \\
\hline Sensor & $9^{12}$ & $3^{13}$ & 2.1 & 1 & 4.8 & 7 \\
\hline Precious Gem & $9^{11}$ & $2^{8}$ & 2.3 & 1 & 5.4 & 8 \\
\hline Lancelot & $9^{7}$ & $4^{8}$ & 2.3 & 1 & 5.4 & 8 \\
\hline Merlin & $9^{11}$ & $2^{11}$ & 1.9 & 1 & 5.5 & 8 \\
\hline 1280 & $8^{6}$ & $1^{5}$ & 2.6 & 2 & 5.2 & 8 \\
\hline Delectable & $9^{11}$ & $3^{12}$ & 2.5 & 2 & 5.8 & 9 \\
\hline 2178 & $9^{4}$ & $3^{2}$ & 2.9 & 3 & 5.2 & 8 \\
\hline Brocade TSW & $9^{10}$ & $3^{8}$ & 2.9 & 3 & 5.7 & 9 \\
\hline 1179 & $8^{3}$ & $2^{3}$ & 2.8 & 3 & 5.9 & 9 \\
\hline Passion & $9^{5}$ & $3^{6}$ & 2.9 & 3 & 6.0 & 9 \\
\hline Devotion & $9^{8}$ & $4^{6}$ & 3.3 & 4 & 5.7 & 9 \\
\hline $282 \mathrm{~A}$ & $9^{9}$ & $3^{7}$ & 3.0 & 4 & 5.8 & 9 \\
\hline Argent & $9^{12}$ & $4^{13}$ & 3.1 & 4 & 5.8 & 9 \\
\hline Vision & $9^{7}$ & $3^{5}$ & 3.3 & 4 & 6.0 & 9 \\
\hline Absolute & $9^{10}$ & $4^{8}$ & 3.2 & 4 & 6.2 & 9 \\
\hline $277 \mathrm{~A}$ & $9^{11}$ & $3^{9}$ & 3.3 & 4 & 6.4 & 9 \\
\hline Miracle & $9^{13}$ & $4^{15}$ & 3.4 & 5 & 6.1 & 9 \\
\hline Jubilee & $9^{13}$ & $4^{14}$ & 3.4 & 5 & 6.2 & 9 \\
\hline Synergy & $8^{5}$ & $4^{5}$ & 3.7 & 5 & 6.6 & 9 \\
\hline Native Gem & $9^{5}$ & $6^{5}$ & 4.1 & 6 & 5.3 & 8 \\
\hline Harvest Gold & $8^{8}$ & $6^{7}$ & 4.1 & 6 & 5.9 & 9 \\
\hline Ambrosia & $9^{13}$ & $6^{13}$ & 4.3 & 6 & 6.2 & 9 \\
\hline Augusta & $9^{5}$ & $6^{5}$ & 4.0 & 6 & 6.4 & 9 \\
\hline White Saturn & $9^{4}$ & $6^{3}$ & 4.3 & 6 & 7.1 & 9 \\
\hline $179 \mathrm{~A}$ & $8^{7}$ & $5^{7}$ & 4.7 & 7 & 6.7 & 9 \\
\hline Bojangles & $9^{7}$ & $5^{6}$ & 4.6 & 7 & 7.3 & 9 \\
\hline \multicolumn{7}{|l|}{ Resistant } \\
\hline El Toro & $3^{13}$ & $3^{12}$ & 2.5 & 2 & 2.8 & 2 \\
\hline Bold & $4^{9}$ & $4^{8}$ & 3.0 & 3 & 4.2 & 6 \\
\hline Snow White & $4^{12}$ & $3^{14}$ & 3.6 & 5 & 5.4 & 8 \\
\hline Eliminator & $2^{13}$ & $6^{14}$ & 3.9 & 6 & 4.2 & 6 \\
\hline Bonus & $2^{13}$ & $6^{12}$ & 4.5 & 7 & 4.8 & 7 \\
\hline
\end{tabular}

${ }^{a}$ Hybrid reactions and number of years of evaluation (as superscript) in University of Illinois disease nurseries prior to these experiments (28).

${ }^{\mathrm{b}}$ Reaction to SCLB and MDM, where $1=$ resistant, $3=$ moderately resistant, $5=$ moderate, $7=$ moderately susceptible, and $9=$ susceptible.

${ }^{\mathrm{c}}$ Severity of SCLB rated on a 1 to 9 scale, where $1=$ chlorotic flecks and $9=$ large, necrotic spots with more than $75 \%$ of tissue blighted. 
tance not only improves control of this important viral disease of sweet corn, but it also lowers the potential for detrimental effects from several other foliar diseases of sweet corn.

\section{ACKNOWLEDGMENTS}

The initial portion of this project was supported by an American Phytopathological Society Frank L. Howard Undergraduate Fellowship Award. We thank Bryan Warsaw, Marci Warren, and Maya Skowron for technical assistance. We thank Crookham Co., Harris Moran Seed Co., Illinois Foundation Seeds Inc., Mesa Maize, Seminis Vegetable Seeds Inc., and Syngenta Seeds Inc. Rogers Brands for providing seed for this study.

\section{LITERATURE CITED}

1. Ataga, A. E., Epton, H. A. S., and Frost, R. R. 1999. Interaction of virus-infected celery and Septoria apiicola. Plant Pathol. 48:620-626.

2. Bateman, D. F. 1961. Synergism between cucumber mosaic virus and Rhizoctonia damping-off of cucumber. (Abstr.) Phytopathology 51:574-575.

3. Beniwal, S. P. S., and Gudauskas, R. T. 1974. Maize dwarf mosaic virus increases susceptibility of sorghum and corn to Helminthosporium maydis race T. Phytopathology 64:11971201.

4. Beute, M. K. 1970. Effect of virus infection on susceptibility to certain fungus diseases and yield of gladiolus. Phytopathology 60:18091813.

5. Beute, M. K. 1973. Increased leaf exudation enhances curvularia leaf spot severity in virusinfected gladiolus. Phytopathology 63:12041205.

6. Beute, M. K., and Lockwood, J. L. 1968 Mechanism of increased root rot in virusinfected peas. Phytopathology 58:1643-1651.

7. Chang, C. M., Hooker, A. L., and Lim, S. M. 1977. An inoculation technique for determining Stewart's bacterial blight reaction in corn. Plant Dis. Rep. 61:1077-1079.

8. Crane, G. L., and Calpouzos, L. 1969. Synergism of Cercospora beticola and beet yellows virus in killing sugar beet leaves. Phytopathology 59:1338-1339.

9. Damsteegt, V. D., and Bonde, M. R. 1993. Interactions between maize streak virus and downy mildew fungi in susceptible maize cultivars. Plant Dis. 77:390-392.

10. Erasmus, D. S., and Von Wechmar, M. B. 1983. Reduction in susceptibility to stem rust (Puccinia graminis f. sp. tritici) by brome mosaic virus. Plant Dis. 67:1196-1198.

11. Farley, J. D., and Lockwood, J. L. 1964. In- creased susceptibility to root rot in virusinfected peas. Phytopathology 54:1279-1280.

12. Futrell, M. C., and Scott, G. E. 1969. Effect of maize dwarf mosaic virus infection on invasion of corn plants by Fusarium moniliforme. Plant Dis. Rep. 53:600-602.

13. Gregory, L. V., and Ayers, J. E. 1982. Effect of inoculation with maize dwarf mosaic at several growth stages on yield of sweet corn. Plant Dis. 66:801-804.

14. Janson, B. F., and Ellett, C. W. 1963. A new corn disease in Ohio. Plant Dis. Rep. 47:11071108.

15. Kerns, M. R., and Pataky, J. K. 1997. Reactions of sweet corn hybrids with resistance to maize dwarf mosaic. Plant Dis. 81:460-464.

16. Lamey, H. A., and Everette, T. R. 1967. Increased susceptibility of hoja blanca virusinfected rice leaves to Cochliobolus miyabeanus. Phytopathology 57:227.

17. Latch, G. C., and Potter, L. R. 1977. Interaction between crown rust (Puccinia coronata) and two viruses of rygrass. Ann. Appl. Biol. 87:139-145.

18. Latterell, F. M., and Rossi, A. E. 1983. Stenocarpella macrospora (=Diplodia macrospora) and $S$. maydis ( $=D$. maydis) compared as pathogens of corn. Plant Dis. 67:725-729.

19. Meyer, M. D. 2010. Studies on sweet corn: Stewart's wilt forecasting, the effect of maize dwarf mosaic on foliar diseases, and herbicide sensitivity. M.S. thesis. University of Illinois, Urbana.

20. Meyer, M. D., and Pataky, J. K. 2008. Increased severity of fungal foliar diseases on sweet corn infected with maize dwarf mosaic. (Abstr.) Phytopathology 98:S105.

21. Mikel, M. A., D'Arcy, C. J., Rhodes, A. M., and Ford, R. E. 1981. Yield response of sweet corn to maize dwarf mosaic virus. Plant Dis. 65:900-901.

22. Mikel, M. A., D'Arcy, C. J., Rhodes, A. M., and Ford, R. E. 1981. Yield loss in sweet corn correlated with time of inoculation with maize dwarf mosaic virus. Plant Dis. 65:902-904.

23. Morant, M. A., Warren, H. L., and von Qualen, S. K. 1993. A synthetic medium for mass production of pycnidiospores of Stenocarpella species. Plant Dis. 77:424-426.

24. Mwanza, N. P. 1966. Viruses as predisposing factors in the susceptibility of corn and wheat plants to other pathogens. Ph.D. diss. Ohio State University, Columbus.

25. Naqvi, N. Z., and Futrell, M. C. 1969. Pathological histology of corn and sorghum plants infected with maize dwarf mosaic virus and Sclerospora sorghi. Plant Dis. Rep. 53:747-751.

26. Nitzany, F. E. 1966. Synergism between $P y$ thium ultimum and cucumber mosaic virus.
Phytopathology 56:1386-1389.

27. Omar, S. A. M., Bailiss, K. W., and Chapman, G. P. 1986. Virus-induced changes in the response of faba bean to infection by Botrytis. Plant Pathol. 35:86-92.

28. Pataky, J. K. 2004. Reactions of sweet corn hybrids to prevalent diseases. Pages 119-142 in: Midwestern Vegetable Variety Trial Repor for 2004. Purdue University, AES Bull. 1838.

29. Pataky, J. K., and Eastburn, D. M. 1993. Using hybrid disease nurseries and yield loss studies to evaluate levels of resistance in sweet corn. Plant Dis. 77:760-765.

30. Pataky, J. K., Michener, P. M., and Freeman, N. D. 1999. Sweet corn hybrid disease nursery-1999. Pages 86-98 in: Midwestern Vegetable Variety Trial Report for 1999. Purdue University, AES Bull. 788.

31. Pataky, J. K., Murphy, J. F., and D'Arcy, C. J. 1990. Resistance to maize dwarf mosaic virus, severity of symptoms, titer of virus, and yield of sweet corn. Plant Dis. 74:359-364.

32. Pataky, J., Williams, M., Warsaw, B., Meyer, M., and Moody, J. 2006. Sweet corn hybrid disease nursery - 2006. Pages 59-74 in: Midwestern Vegetable Variety Trial Report for 2006. Purdue University, AES Bull. B18048.

33. Pazur, C. J., D'Arcy, C. J., and Pataky, J. K. 1985. Effects of dual infection with maize dwarf mosaic virus and Puccina sorghi on sweet corn. Phytopathology 75:965.

34. Potter, L. R. 1982. Interaction between barley yellow dwarf virus and rust in wheat, barley, and oats, and the effects on grain yield and quality. Ann. Appl. Biol. 100:321-329.

35. Stevens, C., and Gudauskas, R. T. 1982. Relation of maize dwarf mosaic virus infection to increased susceptibility of corn to Helminthosporium maydis race $\mathrm{O}$. Phytopathology 72:1500-1502.

36. Suparyono, and Pataky, J. K. 1989. Influence of host resistance and growth stage at the time of inoculation on Stewart's wilt and Goss's wilt development and sweet corn hybrid yield. Plant Dis. 73:339-345.

37. Tu, J. C., and Ford, R. E. 1968. Effect of maize dwarf mosaic virus on respiration and photosynthesis of corn. Phytopathology 58:282-284.

38. Tu, J. C., and Ford, R. E. 1971. Maize dwarf mosaic virus predisposes corn to root rot infection. Phytopathology 61:800-803.

39. Watson, R. D., and Guthrie, J. W. 1964. Virusfungus interrelationships in a root rot complex in red clover. Plant Dis. Rep. 48:723-727.

40. Williams, L. E., and Alexander, L. J. 1965 Maize dwarf mosaic, a new corn disease. Phytopathology 55:802-804.

41. Yarwood, C. E. 1951. Association of rust and virus infections. Science 114:127-128. 